\title{
Significance of constructing teaching-quality monitoring system to the development of higher education
}

\author{
Cai Liu \\ Dean's Office, Jilin University of Finance and Economics, Jilin 130117, China
}

\begin{abstract}
Under the continuous development of Chinese higher education reforms, we've made significant progress upon the higher educations. In the new trend of higher education development, constructing an internal teaching-quality monitoring system is an effective way to improve the teaching quality. Study further upon the teaching-quality monitoring system construction has a deep meaning for the development of higher educations.
\end{abstract}

\section{Introduction}

A higher education institution's development is highly depending on its teaching quality, without a high teaching quality, the talents which could satisfy the society's needs can hardly be cultivated. But how could we improve and maintain the teaching quality? To construct an effective teaching-quality monitoring system is a good approach. The teaching-quality monitoring system plays a leading role in maintaining, modifying and improving the teachings. Given that the systemized operation of teaching-quality monitoring system enabled the dynamic management of teaching qualities, thus constructing a scientific teaching-quality monitoring system is an effective approach to improve the teaching-quality and enable the sustainable development of higher educations.

\section{The present monitoring system of teaching-quality in higher education institutions}

The teaching-quality is the result of teaching effect and an expression of teaching value. Due to the difference between teaching process and general production process, as a result, the teaching product is different from general goods. Teaching products are people who are thoughtful, conscious, and capable of improving themselves. Therefore, the conception of teaching-quality is more complicated than product quality and working quality. However, the present monitoring system in higher education institutions of teaching-quality is not enough to ensure the steady improvement of teaching quality.

The styles of assessment for teaching-quality in higher education institutions are very single which mainly consist of two parts: students grade teachers, experts grade teachers. The fact is that teaching has two aspects, one is teaching and the other is studying. While these two methods of grading only grade teachers from the teach point rather than the combination of teaching and studying. This is the main defect in the process of assessing the teaching quality.

The assessment of teaching-quality in higher education institutions usually pays attention to result rather than process which directly leads to the lack of monitoring and guiding. In this way, the scrutiny and guidance are inefficient

Higher education institutions usually arrange some retired professors to found a monitor committee to scrutinize the teaching quality. This method improves the teaching-quality to some extent but also has shortcomings. First, the workload of scrutiny is continuing to increase with the increase of students and the lack of professors. Second, retired professors' knowledge is different from the practical teaching due to the time difference. As a result, the monitored teachers could only get a limited guidance from the retired professors.

\section{Constructing the monitoring system of teaching-quality should insist the following points}

\subsection{Students should be mainstay and we also should take students as a starting point}

The establishment of monitoring system on teaching-quality should insist the dominant position of students and pay full attention to it. Regard every operation as the starting and standing points of teaching operations, and also see the operations as a way to serve students, for the students. Be more concerned about the community and the employer's needs on the graduates' abilities and the curriculum planning. Based on this demand, higher education institutions should adjust the quality standards, improve the training goal, professional

a Corresponding author: guotianbao1999@126.com 
structure, curriculum and teaching content.

\subsection{Proceeding from reality in everything, adhere to the scientific guidance}

The construction of the teaching-quality monitoring system should persist in proceeding from reality in everything, adhere to the scientific guidance, pay attention to our actual situation when establishing the evaluation index system, choose suitable system which fits the goals, formulate detailed evaluation standards. And make sure it satisfies the requirement of teaching quality, at the same time, the teacher could achieve this goal through their own efforts. Establishing a scientific and reasonable teaching-quality monitoring system and an evaluation index system can improve the teaching level which also could play a positive guiding role. It is helpful to arouse the enthusiasm of teachers and students, and it is also helpful to make teaching reformation conduct smoothly, thus makes the teaching operations develop in the direction of the scientific and efficient.

\subsection{Insisting the operability on the monitoring system}

The monitoring of teaching-quality should follow the principle of putting people first. And pay high attention to it, unify the recognition. Because it involves all aspects of school operations. No matter the operations are of any department, the operations should insist full process, full participation, overall management, full implementation of the whole process. Emphasize teachers' and students' "quality consciousness", put quality monitoring into each link, level and subsystem of teaching. Therefore, the establishment of monitoring system on teaching-quality should not only ensure the integrity of their indicators, but also the operability.

\section{The constitution of teaching-quality monitoring system}

\subsection{Elements in teaching-quality monitoring system}

Elements in teaching-quality monitoring system is the object carrier and operating mechanism of teaching-quality management, which can guarantee the system operate efficiently, the system including: the president of higher education institutions, staff of Teaching Guidance Committee and Educational Administration Office, whose responsibility is to formulate the teaching-quality management plan, making a good arrangement of teaching and teaching-quality control, and making a quality management for departments on behalf of the higher education institutions; second level institutions (Department, school) and teaching-quality monitoring and management institutions and personnel, whose responsibility is making united leading and management according to the school guidance of quality management theory and teaching, on the teaching plan, teaching arrangement, teaching examination, teachers' teaching activities and students' learning activities, leadership and management. Teaching and researching section (Laboratory) is the basis of teaching-quality monitoring. Its responsibility is making efficient organization and management According to the objectives and teaching plan of the school's two grade teaching-quality management, the effective organization and management of each teaching circle.

\subsection{Collection of teaching-quality information}

Information collection is the feedback of the teaching-quality monitoring system. The comprehensive and accurate information is an important element of evaluation, diagnosis and feedback. At the academic level, one is that the use of the term (early, middle and late) teaching examination, examination, collection of student information, the organize the department staff to listen to lectures and other ways to collect information; another is that through the experimental teaching examination, the curriculum design examination, the specialized practice examination, the graduation project quality inspection and so on to carry on the quality control and teaching activity and the practice teaching. Third is through listening to the opinions of the student's information to obtain the relevant information to modify teaching and training programs and other related content. Forth is to establish teaching evaluation group and teaching monitoring group. Fifth is to establish an interactive platform for quality monitoring information system.

\subsection{Teaching-quality evaluation system}

Education is an important means to judge the quality of teaching. The purpose of educational evaluation is to improve the teaching quality, promote the education reform, improve the education management and make the decision to promote the progress of education. According to the specific evaluation, we need to develop various teaching links (including: the evaluation index system of classroom teaching evaluation, experimental teaching-quality standard and evaluation index, evaluation index and quality standards of professional practice, curriculum design and quality standards and evaluation index), the professional construction of evaluation index system of excellent course construction, evaluation index system.

\subsection{Teaching-quality information feedback and control system}

Teaching-quality information feedback and control system is an important subsystem of the teaching-quality monitoring system, which makes it become the necessary condition of the closed loop system. The school makes it possible that through a variety of ways and means, teaching-quality assessment, checking all information will be obtained (teaching information, check the daily teaching information, and in the end, at the beginning of the semester of teaching inspection information, exam 
information, teaching monitoring information, student information, student achievement information, graduation practice graduation design information, etc.) through analysis, diagnosis and treatment, timely feedback to constantly adjust and improve the work, and improve the quality of teaching. In order to widen the channel of information feedback, teachers, students and administrators will interact in feedback systems, and the feedback information will be sent to all units or teachers in various forms. In the premise of protect the enthusiasm of teachers' teaching, we provide the information feedback timely and accurately.

\section{To achieve dynamic management of teaching-quality through systemizing the teaching-quality monitor}

Perfect all sorts of teaching rules and regulations. Original specialty training program, teaching plan and teaching management system should be revised to promote the standardization and institution of teaching management.

The main system for teaching-quality monitoring includes: 1, system of teaching supervisor. The supervisor team is responsible for monitoring of teaching work in school, providing constructive suggestions to leaders in department and dean's office in terms of specialty's teaching plan, course construction and specialty construction; they should have regular inspection on teaching plan and teaching facilities, take teaching observation regularly and make objective comments and directions on teaching contents, methods and organizing of teaching process, to help teacher improve their methods and teaching efficiency; they also have the responsibility to check papers of each major, and their marking condition, to make comments through analysis of test paper. They need to check students' studies, take their advice and transfer it into dean's office in time in order to promote education. 2, system of inspection tour by department leaders. Inspection includes not only the preparation for teaching like classroom environment, students' attendance, multimedia operation, and teaching plan...but also the teaching part in class (classroom dynamic, initiative of student and teacher, teacher's teaching level and his education style). 3, system of observation. The school leaders, teaching administration staff, head of teaching group and college all of them need to attend teaching observation. 4, system of regular teaching inspection. 5, system of regular teaching meeting. 6 , system of teaching-quality evaluation. It includes all kinds of evaluation of students, the supervisor team, management staff, college and teachers teaching. 7, system of collective lesson preparation. 8, system of experimental teaching. 9, system of symposium. (teaching management staff symposium, teacher symposium and student symposium). 10, system of student liaison and other systems.

By means of rolling out and implementing a set of sensible rules and regulations, optimizing administrations and raising services, our teaching works are in sound operations. Not only the teachers' pedagogies and the administrators' responsibilities, but the students' behaviors have been pushing towards standardization. That means, our teachers put teaching works at a prior place, our administrators put most of efforts into management and service works, and our students are committed to their studies.

Teaching-quality will be affected by many factors during the teachings, because of that, the construction of teaching-quality monitoring system is a complicated job, which needs continuously deepening explorations and practices. we shall be leaded by the thoughts of comprehensive quality management and the basic theory of systems science, adopt series of education and teaching reformations, construct a relatively rounded teaching-quality monitoring system, which plays a big role in the development of higher educations.

\section{References}

1. J. Hang, Chinese Adult Education (2016).

2. T. Wang, Journal of Capital Normal University (2015).

3. X.M. Zhang, Hefei Polytechnic University (2010).

4. X.B. Chen, Nanjing Normal University (2011).

5. N.N. Zhang, Shandong Normal University (2011).

6. B.H. Ma, Vocational and technical education (2009). 